Article

CECCHIN, K. ${ }^{1}$

FAVARETTO, A. ${ }^{1 *}$

SCHEFFER-BASSO, S.M. ${ }^{1}$

BERTOL, C.D. ${ }^{1}$

CHINI, S.O. ${ }^{1}$

\section{Allelopathy and Allelochemicals of Eragrostis plana (PoAceae) and its Relation with Phenology AND Nitrogen Fertilization ${ }^{1}$}

\author{
Alelopatia e Aleloquímicos de Eragrostis plana (Poaceae) e sua Relação com \\ Fenologia e Adubação Nitrogenada
}

\begin{abstract}
This study was conducted in order to verify if the phenological stage and the nitrogen fertilization interfere in the allelopathic activity and in the concentration of potentially allelopathic phenolic compounds of tough lovegrass (Eragrostis plana). The assay consisted of a bifactor $3\left(0.100\right.$ and $\left.200 \mathrm{~kg} \mathrm{~N} \mathrm{ha}^{-1}\right) \times 2$ (harvested in vegetative and reproductive stages), in a split plot design. The $\mathrm{N}$ doses constituted the main plot and the phenological stage during the harvest the subplots, resulting in six treatments. The tough lovegrass plants derived from each of the treatments were subjected to allelopathy bioassays, in which aqueous extracts of the aerial parts were applied to lettuce cypselae (Lactuca sativa) and to phytochemicals tests when ethanolic extracts were used, with subsequent partition with ethyl acetate, followed by a high-performance liquid chromatography analysis. There was nitrogen $\mathrm{x}$ phenological stage interaction on biological and chemical attributes. The allelopathic extracts were, in descending order of inhibition of germination, those from plants harvested at the vegetative stage and fertilized with $100 \mathrm{~kg} \mathrm{~N}$ and at the flowering stage with $200 \mathrm{~kg} \mathrm{~N}$, which showed the highest catechin concentrations. The caffeic, ferulic, p-coumaric and vanillic acids were in a higher concentration in flowered and fertilized plants with 0 or $200 \mathrm{~kg} \mathrm{~N}$. The management of the nitrogen fertilization and the harvesting age influence the allelopathic activity and the phytochemical composition of tough lovegrass.
\end{abstract}

Keywords: germinability, phenolic acids, catechin, epicatechin.
* Corresponding author:

<adriana_f37@hotmail.com>

Received: February 26, 2016

Approved: April 5, 2016

Planta Daninha 2017; v35:e017157907
RESUMO - Este estudo foi realizado com o objetivo de verificar se a fenologia e a adubação nitrogenada interferem na atividade alelopática e na composição fenólica do capim-annoni (Eragrostis plana). O ensaio constou de um bifatorial 3 $\left(0,100\right.$ e $\left.200 \mathrm{~kg} \mathrm{~N} \mathrm{ha}^{-1}\right) \times 2$ (colheita nos estádios vegetativo e reprodutivo), em arranjo de parcela subdividida. As doses de $N$ constituiram a parcela principal, e o estádio fenológico por ocasião da colheita das plantas, as subparcelas, resultando em seis tratamentos. As plantas de capim-annoni, oriundas de cada um dos tratamentos, foram submetidas a bioensaios de alelopatia, em que extratos aquosos da parte aérea foram aplicados sobre cipselas de alface (Lactuca sativa); e a testes fitoquímicos, quando se utilizaram extratos etanólicos, com posterior partição com acetato de etila, seguido de análise por cromatografia líquida de alta eficiência. Houve interação nitrogênio x estádio fenológico sobre a alelopatia e a composição química do capim-annoni. Os extratos com maior potencial alelopático foram, em ordem decrescente de inibição na germinação, aqueles oriundos de plantas colhidas no estádio vegetativo e adubadas com $100 \mathrm{~kg} \mathrm{~N}$ e no estádio de florescimento com $200 \mathrm{~kg} \mathrm{~N}$, que mostraram as maiores concentrações de catequina.

1 Universidade de Passo Fundo, Passo Fundo-RS, Brasil. 
Os ácidos cafeico, ferúlico, vanílico e p-cumárico estiveram em maior concentração nas plantas florescidas e adubadas com 0 ou $200 \mathrm{~kg} \mathrm{~N}$. O manejo da adubação nitrogenada e a fenologia influenciam a atividade alelopática e a composição fenólica do capim-annoni.

Palavras-chave: ácidos fenólicos, catequina, epicatequina, germinabilidade

\section{INTRODUCTION}

The tough lovegrass (Eragrostis plana), a tropical African grass which was introduced in Argentina (1940), in Brazil (1950-1960) and was dispersed throughout Uruguay, is considered the main invasive plant of pastures of the Pampa Biome. The success of this species in colonizing extensive rural and ruderal areas is attributed, in part, to its allelopathic action (Ferreira et al., 2008; Favaretto et al., 2011). Recent studies have indicated the presence of phenolic compounds in the roots and leaves of this grass (Favaretto et al., 2015). Although which of the compounds are responsible for its allelopathic activity were not yet identified, it is known that phenols are allelochemicals (Albuquerque et al., 2010) and once they are leached from plants or released by the decomposition of plant residues, they may inhibit the germination and the growth of other species.

Allelopathy seems to be decisive in the dominance of some invasive plants, for it produces compounds which native plants have no resistance to (Callaway and Ridenour, 2004). This phenomenon consists in the action, direct or indirect, positive or negative, of a plant or microorganism on another by releasing allelochemicals (Rice, 1984). These compounds differ on the structure and the mode of action and represent the possibility of developing new herbicides or pesticides (Li et al., 2010). There are many allelochemicals in plants; however, the most common are the phenolic acid and terpenoids (Su and Yu, 1992), which variation responds to environmental factors, since they are derived from the secondary metabolism (Çirak et al., 2008).

In the tough lovegrass, varying amounts of caffeic, ferulic, vanillic and p-coumaric acids, of proanthocyanidin monomers (catechin and epicatechin) and of coumarin were verified according to the vegetal organ (Favaretto et al., 2015). Until the execution of the present study, no information was available on the influence of the phenology and of the nitrogen fertilization on the concentration of these compounds.

The availability of nitrogen $(\mathrm{N})$ is one of the main factors to be investigated in such studies because of the impact of this nutrient in the growth, production and biomass allocation, and in the chemical composition of plants. Nevertheless, there is no clarity about its effect on the allelopathic activity and on the concentration of allelochemicals. Some authors mention the increase of secondary metabolites under low $\mathrm{N}$ availability in the soil (Ibrahim et al., 2011), while others indicate that $\mathrm{N}$ increases the concentration of phenolic acids (Chou and Lee, 1988; Ma et al., 2015). Phenolic compounds may, in turn, be in a higher or a lower concentration, depending on the physiological age of the plants. As these compounds are directly involved in the association of the lignin with the hemicellulose from the cell wall (Deschamps and Ramos, 2002), the increase of its concentration in plants is commonly observed in advanced phenological stages.

This study was conducted in order to verify if the phenology and the nitrogen fertilization interfere in the allelopathic activity and in the phenolic composition of the tough lovegrass.

\section{MATERIAL AND METHODS}

The fieldwork was conducted in a secondary vegetation area with predominance of tough lovegrass in Passo Fundo ( $28^{\circ} 15^{\prime}$ 'S, $52^{\circ} 24^{\prime} \mathrm{W}$ ), from September 2013 to January 2014. The region's climate is subtropical type $\mathrm{Cfa}$. The information about the mean temperatures and the precipitations that occurred during this period are shown in Figure 1. The soil of the area was sampled with five randomly distributed spots. An auger was used to make the samples at a layer of $0-10 \mathrm{~cm}$ in depth. The soil was characterized by the following attributes: $40.7 \%$ of clay; $\mathrm{pH} 5.3$ 


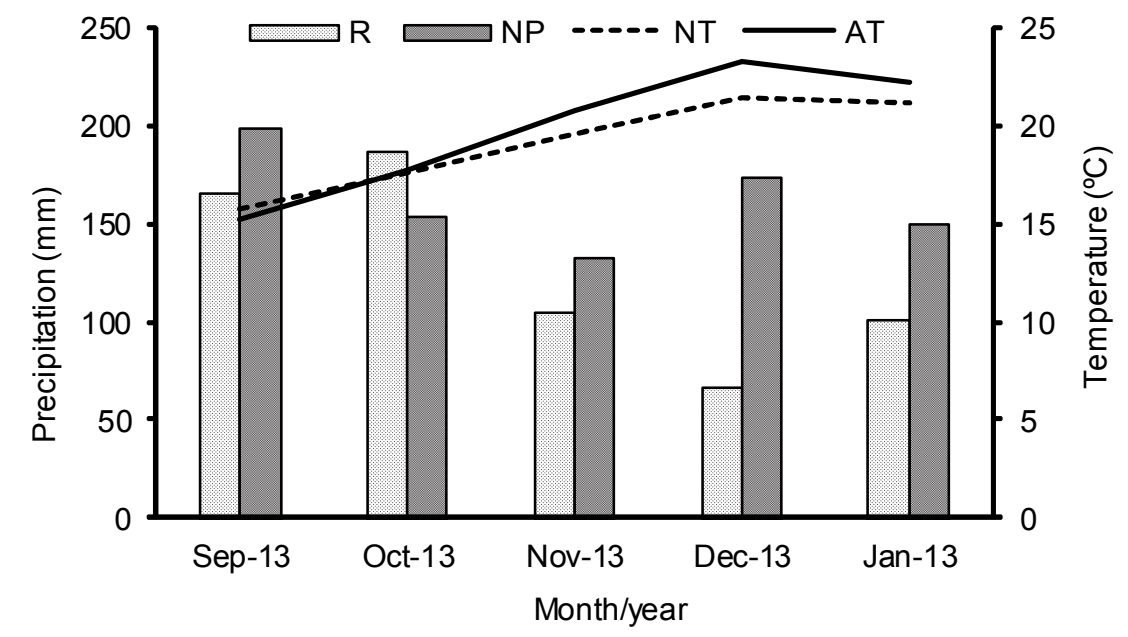

AT: Average temperature; NT: Normal temperature; R: Rainfall; NP: Normal precipitation.

Source: Embrapa Trigo (2014).

Figure 1 - Average temperatures and monthly precipitations occurred during the growth period of the plants.

in water; $6.6 \mathrm{mg} \mathrm{dm}^{-3}$ of $\mathrm{P} ; 164 \mathrm{mg} \mathrm{dm}^{-3}$ of $\mathrm{K} ; 3.7 \%$ of organic matter; $0.3 \mathrm{cmol}_{\mathrm{c}} \mathrm{dm}^{-3}$ of $\mathrm{Al}$; $4.2 \mathrm{cmol}_{\mathrm{c}} \mathrm{dm}^{-3}$ of Ca; $1.9 \mathrm{cmol}_{\mathrm{c}} \mathrm{dm}^{-3}$ of $\mathrm{Mg} ; 10 \mathrm{mg} \mathrm{dm}^{-3}$ of S; $30.9 \mathrm{mg} \mathrm{dm}^{-3}$ of $\mathrm{Mn} ; 0.5 \mathrm{mg} \mathrm{dm}^{-3}$ of Bo; $1.20 \mathrm{mg} \mathrm{dm}^{-3}$ of $\mathrm{Zn}$; and $2.1 \mathrm{mg} \mathrm{dm}^{-3}$ of $\mathrm{Cu}$. In order to reduce the acidity and to increase the phosphorus concentration, the equivalent of 2 ton ha ${ }^{-1}$ of limestone and $72 \mathrm{~kg} \mathrm{ha}^{-1}$ of $\mathrm{P}_{2} \mathrm{O}_{5}$, was respectively applied at the surface, immediately after mowing, followed by the removal of the vegetable material of the soil surface.

The assay consisted of a bifactor $3\left(0.100\right.$ and $\left.200 \mathrm{~kg} \mathrm{~N} \mathrm{ha}^{-1}\right) \times 2$ (harvested at the vegetative and at the reproductive stages), in a split plot design. The $\mathrm{N}$ doses constituted the main plot $\left(8 \mathrm{~m}^{2}\right)$ and the phenological stage during the harvest the subplots $\left(4 \mathrm{~m}^{2}\right)$, resulting in six treatments: $0 \mathrm{~kg} \mathrm{ha}^{-1}$ of $\mathrm{N}+$ harvest at the vegetative stage (OVEG), $100 \mathrm{~kg} \mathrm{ha}^{-1}$ of $\mathrm{N}$ applied + harvest at the vegetative stage (100VEG) and $200 \mathrm{~kg} \mathrm{ha}^{-1}$ of $\mathrm{N}+$ harvest at the vegetative stage (200VEG), $0 \mathrm{~kg} \mathrm{ha}^{-1}$ of $\mathrm{N}+$ harvest at the reproductive stage (OREP), $100 \mathrm{~kg} \mathrm{ha}^{-1}$ of $\mathrm{N}$ applied + harvest at the reproductive stage (100REP), $200 \mathrm{~kg} \mathrm{ha}^{-1}$ of $\mathrm{N}+$ harvest at the reproductive stage (200REP). The design was completely randomized with four replications. The $\mathrm{N}$ doses (applied as urea) were divided into two applications, in early spring, with an interval of 15 days.

The first harvest of the vegetable material to be used in the preparation of the extracts was performed when the plants were at the vegetative stage, after 77 days of growth, which was on the 60th day after the last application of $\mathrm{N}$; the second harvest was held at the reproductive stage, characterized by the presence of fully expanded inflorescences and most spikelets in anthesis, after 128 days of growth, which occurred on the 50th day after the first harvest and 110 days after the last application of $\mathrm{N}$. The harvest was performed by cutting all vegetable material present in the subplot close to the ground, then the botanical separation was performed in order to separate the tough lovegrass from the other plants. Next, the fresh matter was weighed and a sample of $500 \mathrm{~g}$ was separated which had its leaves and blooming stems separated. These components were dried in a forced air oven at $60{ }^{\circ} \mathrm{C}$ for 72 hours, with a subsequent weighing to determine its proportion in the sample. After this weighing, the components were collected, ground and subjected to analysis of the $\mathrm{N}$ concentration using the Kjeldahl method. The rest of the vegetable material of each plot was dried in a forced air oven at $35{ }^{\circ} \mathrm{C}$ until constant weight was obtained, followed by its grinding in the micromill in order to be used in the preparation of the extracts.

To verify the allelopathic activity of the tough lovegrass in the germinability of lettuce (Lactuca sativa), a species susceptible to the allelopathic compounds, aqueous extracts were prepared at a concentration of $15 \%$. To this end, $15 \mathrm{~g}$ of the vegetable material were mixed with $100 \mathrm{~mL}$ of distilled water, followed by a 24 hours' period in the dark, at room temperature, according to the static maceration method (Soares and Vieira, 2000), followed by filtering. The design of 
treatments consisted of a different factor, in which the treatments resulting from the combination of $\mathrm{N} x$ phenology factors, a control was added (distilled water). Thus, the bioassay was composed of treatments $(6$ extracts + control), which were arranged in a completely randomized design with four replications.

The experimental units consisted of gerbox boxes in which fifty cypselae were placed and equidistantly arranged on moistened germitest paper with $9 \mathrm{~mL}$ of each extract and of the control (distilled water). After the application of the treatments, the boxes were sealed with plastic film to prevent the loss of water by evaporation, and were kept in a germination chamber at $20{ }^{\circ} \mathrm{C}$ and a photoperiod of 12 hours for ten days. The counting of the germinated seeds was performed daily, and from these data the germinability and the germination speed index (GSI) were calculated.

In order to assess the concentration of the phenolic compounds in plant tissues, six semipurified extracts, resulting from the factorial $3 \times 2$ (nitrogen $\times$ phenological stage), were tested. Extracts were prepared with $10 \mathrm{~g}$ of vegetable material, previously dried and ground, kept under reflux for an hour with $485 \mathrm{~mL}$ of $95 \%$ ethanol and $15 \mathrm{~mL}$ of hydrochloric acid (97: 3) (Harborne, 1984; Dey and Harborne, 1989). Subsequently, this material was filtered and concentrated on a rotary evaporator under reduced pressure and at an $80^{\circ} \mathrm{C}$ temperature until dry extracts were obtained. Then, these extracts were resuspended in $150 \mathrm{~mL}$ of distilled water and partitioned with ethyl acetate, thus, obtaining a semi-purified fraction. These fractions were again concentrated in a rotary evaporator, and from this material $0.05 \mathrm{~g}$ of each sample was resuspended in $5 \mathrm{~mL}$ of HPLC grade methanol. After the resuspension, the fractions were filtered through a nylon membrane containing pores with a diameter of $0.45 \mu \mathrm{m}$ for an analysis using highperformance liquid chromatography (HPLC).

The following secondary metabolites were quantified: phenolic acids (caffeic, p-coumaric, ferulic, gallic, and vanillic acids) and forming procyanidin monomers (catechin, epicatechin). Solutions $\left(1,000 \mu \mathrm{g} \mathrm{mL}^{-1}\right)$ were prepared by dissolving $0.1 \mathrm{~g}$ of chemicals of reference in a volumetric flask with $100 \mathrm{~mL}$ of HPLC grade methanol. The mobile phase used for the compounds was ultrapure water obtained by the Direct-Q System - Millipore ${ }^{\circledR} /$ Millipore Corporation (US) with a specific $\mathrm{pH}$ for each compound and acetonitrile in different proportions: a) for caffeic, ferulic, $\mathrm{p}$ coumaric and vanillic acids: acetonitrile: water pH 3.4 (25:75); b) gallic acid: acetonitrile: water pH 3.0 (10:90); c) catechin and epicatechin: acetonitrile: water pH 3.0 (18:82).

The analyzes were performed on a PerkinElmer Flexar LC High-Performance Liquid Chromatograph containing a binary pump, an Autosampler and a PDA variable wavelength detector in 280 and $274 \mathrm{~nm}$, in which the chromatographic data were analyzed in the Chromera Workstation Software. The ACE C18 reverse phase column $(250 \times 4.6 \mathrm{~mm}, 5 \mu \mathrm{m})$ and a guard column of the same material were used. Aliquots of $20 \mu \mathrm{L}$ of the extracts were injected in triplicate. The compounds present in each extract were identified and quantified.

The allelopathy bioassay data were submitted to Anova, in the differentiated factorial model $(A x B+1)$. With this procedure there was the verification of the effect of the individual factors of the interaction $\mathrm{AxB}$ and the interaction $\mathrm{AxB}$ with the control. The comparison of treatment means in relation to the control was taken by Dunnett's test (Vieira and Hoffmann, 1989) and the comparison of the extracts means was taken by Tukey test, both at a $5 \%$ probability. The data on dry matter production, botanical composition of the vegetable material, $\mathrm{N}$ concentration and concentration of the phenolic compounds were analyzed by Anova, in a split plot design, with comparison of means by Tukey test at a 5\% probability. The statistical analyzes were performed using the computer program Assistat version 7.7 (Silva and Azevedo, 2002).

\section{RESULTS AND DISCUSSION}

The nitrogen fertilization and the harvest at different phenological stages (PS) resulted in vegetable material with different concentrations of $\mathrm{N}$, proportion of leaves and blooming stems, as well as in the production of dry matter (Table 1). The tough lovegrass had a positive response to the $\mathrm{N}$ application, especially in plants harvested at the reproductive stage, where there was a significant difference among the tested doses. At the vegetative stage, probably because the time between the applications of $\mathrm{N}$ and the harvest was the shortest, there was no difference 
among doses. In the tough lovegrass that was not fertilized with N, Alfaya et al. (2002) found 1.3\% of $\mathrm{N}$ in young plants (30 days) and $0.9 \%$ in plants of 150 days. The highest $\mathrm{N}$ concentrations verified in plants harvested at the vegetative stage are commonly found in grass, since that at this stage of development there is a predominance of leaves, as observed in this study (Figure 2).

Table 1 - Production of dry matter (DM) and nitrogen concentration $(\mathrm{N})$ of the tough lovegrass in response to the nitrogen fertilization and the phenological stage at harvest

\begin{tabular}{|c|c|c|}
\hline \multirow{2}{*}{$\begin{array}{c}\text { Nitrogen } \\
\left(\mathrm{kg} \mathrm{ha}^{-1}\right)\end{array}$} & \multicolumn{2}{|c|}{ Phenological stage } \\
\cline { 2 - 3 } & \multicolumn{2}{|c|}{ Dry matter $\left(\mathrm{kg} \mathrm{ha}^{-1}\right)$} \\
\hline 0 & $247 \mathrm{bA}$ & $466 \mathrm{cA}$ \\
\hline 100 & $486 \mathrm{abB}$ & $1080 \mathrm{bA}$ \\
\hline 200 & $551 \mathrm{aB}$ & $1455 \mathrm{aA}$ \\
\hline & \multicolumn{2}{|c|}{$\mathrm{N}(\%)$} \\
\hline 0 & $1.49 \mathrm{bA}$ & $1.20 \mathrm{bB}$ \\
\hline 100 & $1.78 \mathrm{aA}$ & $1.22 \mathrm{bB}$ \\
\hline 200 & $1.92 \mathrm{aA}$ & $1.57 \mathrm{aB}$ \\
\hline
\end{tabular}

Means followed by the same letter, uppercase on the line and lowercase on the column, do not differ by the Tukey test $(p<0.05)$.

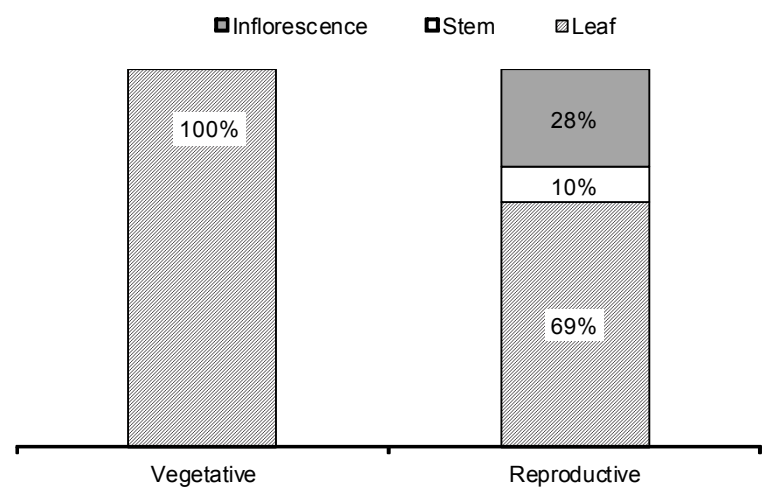

Figure 2 - Proportion of leaf, stem and inflorescence in the dry mass of the aerial part of the tough lovegrass harvested at the vegetative and reproductive stages, in the mean of nitrogen doses.

The allelopathic effect of the aqueous extracts on lettuce was visually observed (Figure 3) and quantified according to the germinability and the GSI (Table 2), in accordance with other authors who evaluated the allelopathic potential of the tough lovegrass (Ferreira et al., 2008; Favaretto et al., 2011). The allelopathic symptoms, in a greater or a lesser degree and depending of the extract, included necrosis, shortening and winding of the root apex (Figure 3), which is commonly reported in bioassays of this type (Souza Filho et al., 1997). These symptoms were observed in white clover seedlings (Trifolium repens, Fabaceae) that were subjected to leaf and root extracts of the tough lovegrass (Favaretto et al., 2011).

The nitrogen fertilization and the phenology showed an interactive effect on the attributes of the seed germination. Two (100VEG; 200REP) of the six extracts were allelopathic on seeds of the target species. Nevertheless, the allelopathic effect of the 100VEG extract was three times higher than the one observed in the 200REP extract. Considering that the $\mathrm{pH}$ of the extracts was in the appropriate range for the type of test (Oliveira et al., 2012) and that the values were similar among the extracts, the variation in the germinability and in the GSI is attributed to the combined effect of the $\mathrm{N}$ and of the phenology. The relation between the allelopathic activity and the maturity of plants was observed in sorghum (Sorghum sp., Poaceae) (Marchi et al., 2008) and in fenugreek (Trigonella foenum-graecum, Fabaceae) (Omezzine et al., 2014), in which plants harvested at the vegetative stage originated more allelopathic extracts compared to those elaborated with plants in a more advanced stage of development, thus it can be deduced that this fact occurred due to the increase in the amount of bioactive compounds.

Studies on the response of the tough lovegrass to nitrogen fertilization are limited.

Table 2 - Germinability and germination speed index (GSI) of lettuce subjected to aqueous extracts prepared with the aerial part of the tough lovegrass fertilized with increasing doses of nitrogen and harvested at different phenological stages

\begin{tabular}{|c|c|c|}
\hline \multirow{3}{*}{$\begin{array}{l}\text { Nitrogen } \\
\left(\mathrm{kg} \cdot \mathrm{ha}^{-1}\right)\end{array}$} & \multicolumn{2}{|c|}{ Phenological stage } \\
\hline & Vegetative & Reproductive \\
\hline & \multicolumn{2}{|c|}{ Germinability (\%) } \\
\hline 0 & $97 \mathrm{Aa}$ & $93 \mathrm{Aa}$ \\
\hline 100 & $25 * \mathrm{Bb}$ & $90 \mathrm{Aa}$ \\
\hline 200 & $83 \mathrm{Aa}$ & $70 * \mathrm{Ab}$ \\
\hline Control & \multicolumn{2}{|c|}{99} \\
\hline & \multicolumn{2}{|c|}{ GSI } \\
\hline 0 & $16 \mathrm{Aa}$ & $14 \mathrm{Aa}$ \\
\hline 100 & $3 * \mathrm{Bb}$ & $13 \mathrm{Aab}$ \\
\hline 200 & $12 \mathrm{Aa}$ & $10 * \mathrm{Ab}$ \\
\hline Control & \multicolumn{2}{|c|}{43} \\
\hline
\end{tabular}

Means followed by the same letter, uppercase on the line and lowercase on the column, do not differ by the Tukey test $(\mathrm{p}<0.05)$ * indicates difference in relation to the control (distilled water) by the Dunnett test $(\mathrm{p}<0.05)$. 


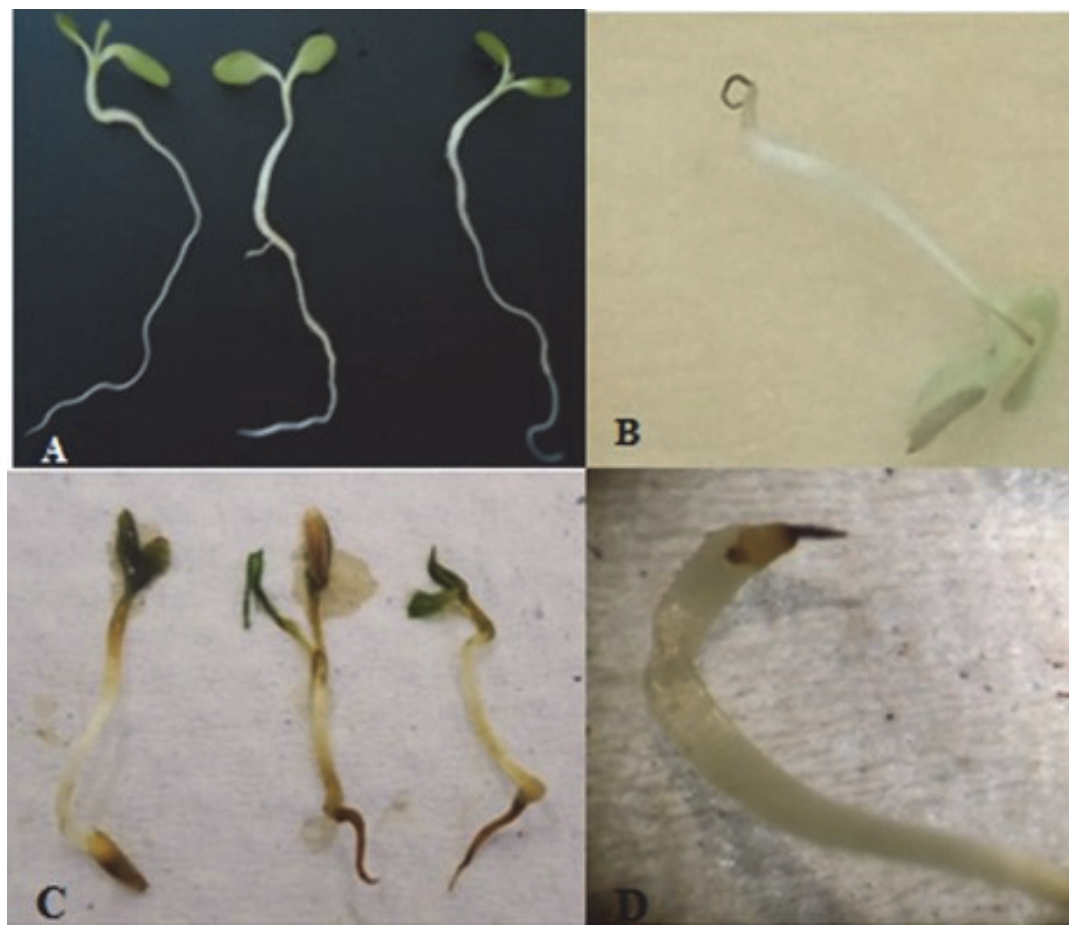

Figure 3 - Abnormalities of lettuce seedlings subjected to aqueous extracts of tough lovegrass prepared with plants collected at the vegetative stage at doses of 0 (B), 100 (C) and $200 \mathrm{~kg} \mathrm{ha}^{-1}$ (D) compared to the control (A).

Focht and Medeiros (2012) performed a study utilizing nitrogen/phosphorus fertilization, in which there was no response of this grass in terms of population density. This study, as so far observed, contains the first record of the effect of nitrogen fertilization on the allelopathic activity of the tough lovegrass. Nonetheless, there is some evidence of this relation to other species. In tall fescue (Festuca arundinacea, Poaceae), the nitrogen fertilization resulted in a higher allelopathic activity of the extracts on the germination and growth of seedlings of birdsfoot trefoil (Lotus corniculatus, Fabaceae) (Luu et al., 1982). A positive relation between the $\mathrm{N}$ doses and the allelopathic potential was found on rice (Hu et al., 2003). Aqueous extracts of chicory (Cichorium intybus, Asteraceae) derived from combined treatments of $\mathrm{pH}$ and $\mathrm{N}$ had influence in the germination and growth of tall fescue, white clover and alfalfa seedlings (Medicago sativa, Fabaceae) (Wang et al., 2012).

The phenolic compounds evaluated in this study, quantified in alcoholic extracts, in order of importance, by their concentration $\left(\mathrm{mg} \mathrm{g}^{-1}\right)$, were: $\mathrm{p}$-coumaric acid (9.13)> vanillic acid (6.38)> epicatechin (2.98)> ferulic acid (0.89)> catechin (0.77)> caffeic acid (0.62) (Figures 4 and 5). The extracts of the flowered plants exhibited a total concentration of phenolic acids 3.5 times higher than the ones obtained in plant extracts at the vegetative stage, with less effect of this factor on catechin and epicatechin (Figure 5). Considering that the lignin is a phenolic polymer consisting essentially of p-coumaric and ferulic acids (Jung and Deetz, 1992), the increase of the amount of the phenolic acids in adult plants is compatible with the dynamics of the lignification. On average, with the flowering, it was observed an increase by $40 \%, 237 \%, 266 \%$ and $966 \%$ in the concentration of caffeic, vanillic, ferulic and p-coumaric acids, respectively, compared to the results verified at the vegetative stage.

Abiotic stress due to high temperatures and low rainfall are determinant in the lignification of plants. In this study, the period between the uniformity cut and the harvest at the vegetative stage was of mild climate and high rainfall $(402 \mathrm{~mm})$, thus, the stress that could be caused by such factors can be disregarded. As the spring progressed, the temperatures increased with average of $22{ }^{\circ} \mathrm{C}$ in the period between the harvest at the vegetative stage and the cut made at the reproductive stage. In this second stage of plant growth, the precipitation was below the historical series (Figure 1), in which a period of severe deficiency of water occurred. This condition is one of the factors that increases the concentration of secondary metabolites in plants (Gobbo Neto and Lopes, 2007). 


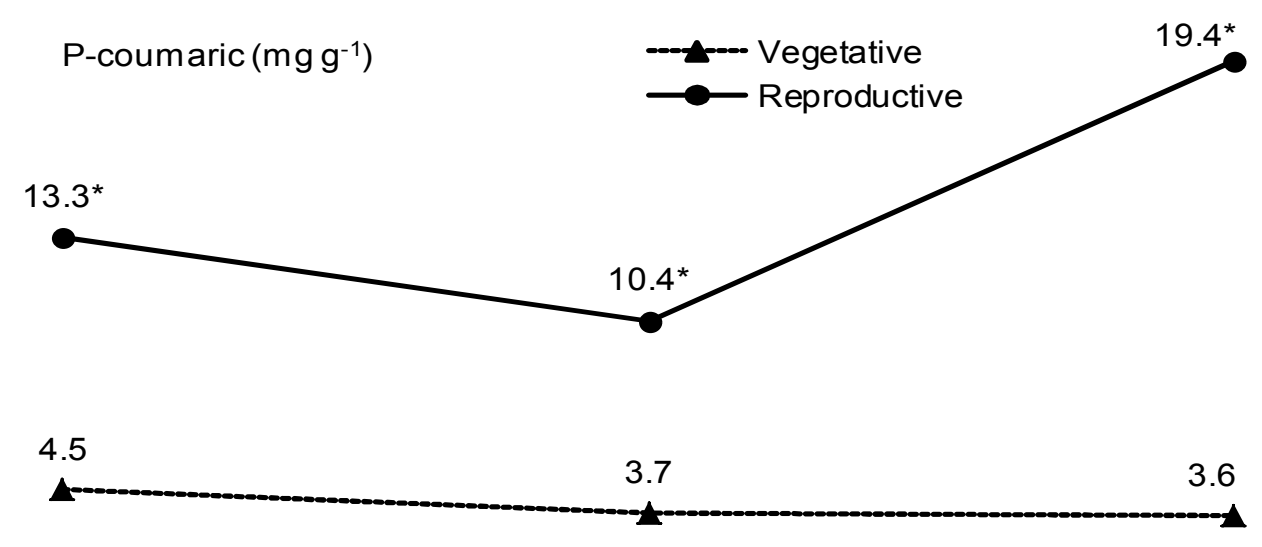

Ferulic acid $\left(\mathrm{mg} \mathrm{g}^{-1}\right)$
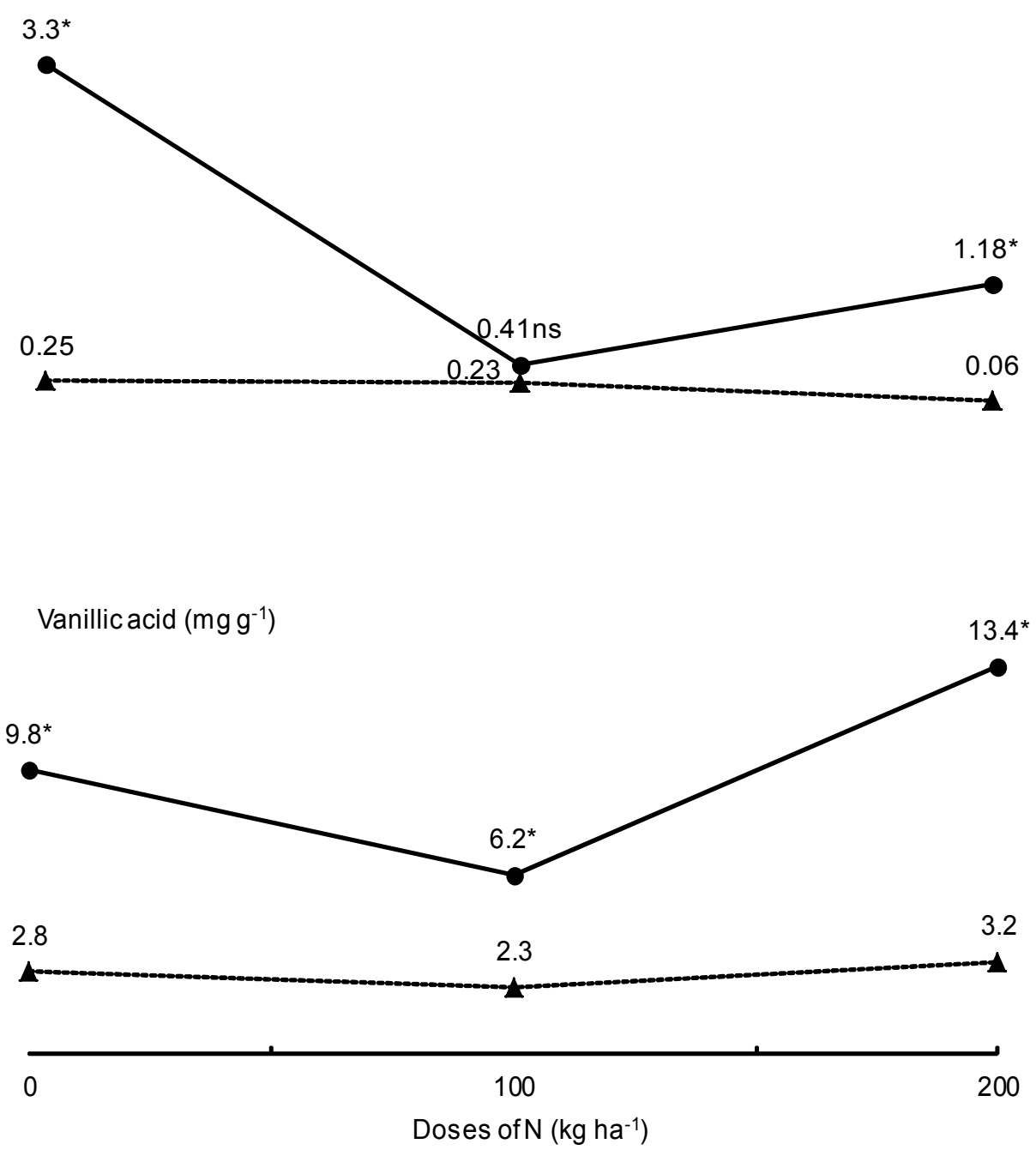

$* \mathrm{p}<0.05$ (Tukey test).

Figure 4 - Effect of the phenological stage in the concentration of ferulic (A), caffeic (B), vanillin (C) and p-coumaric acids (D) in alcoholic extracts of tough lovegrass according to the nitrogen fertilization $(\mathrm{N})$. 


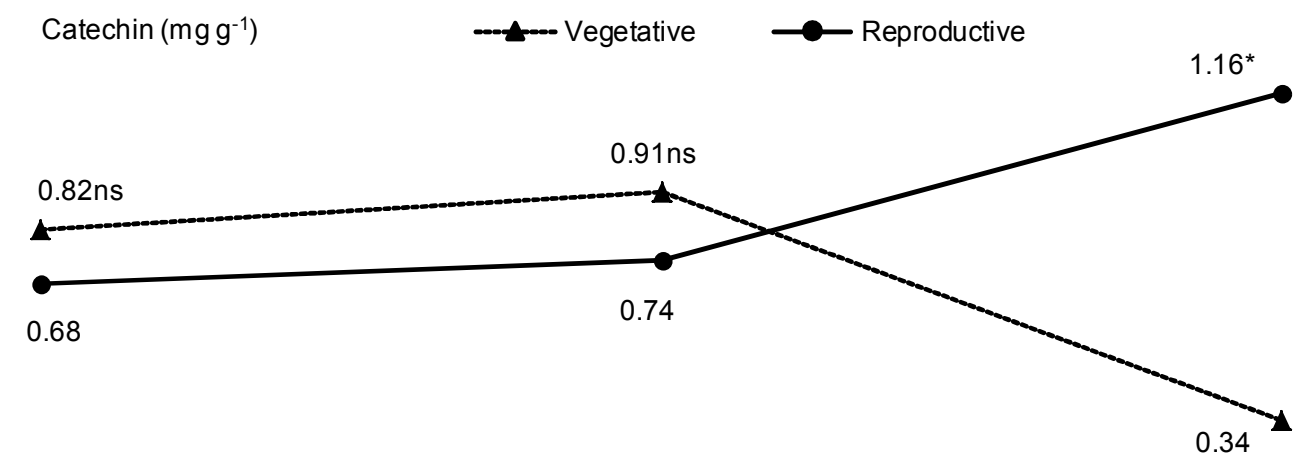

Epicatechin $\left(\mathrm{mg} \mathrm{g}^{-1}\right)$

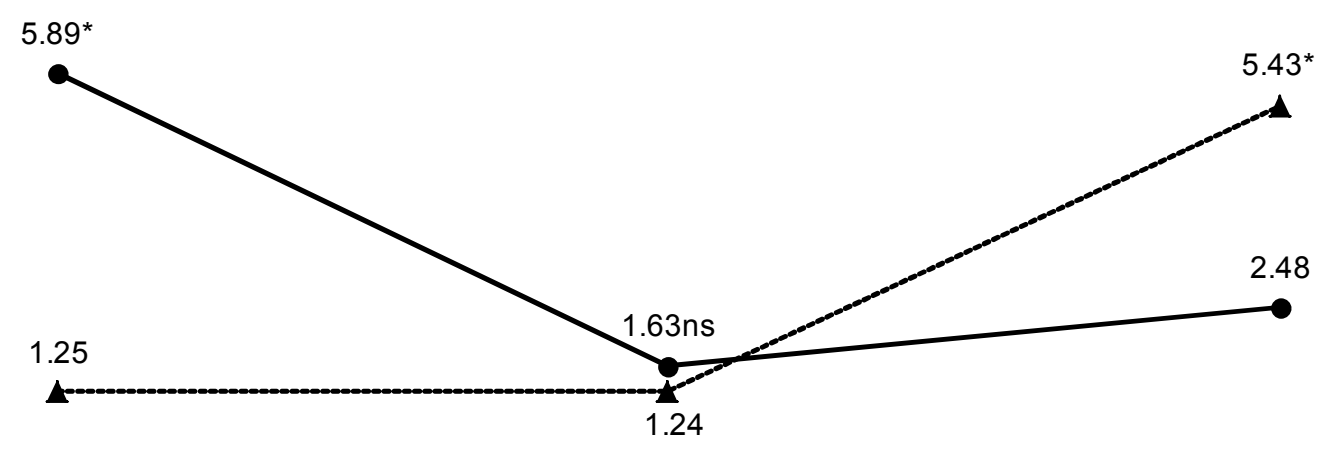

Caffeic acid $\left(\mathrm{mg} \mathrm{g}^{-1}\right)$

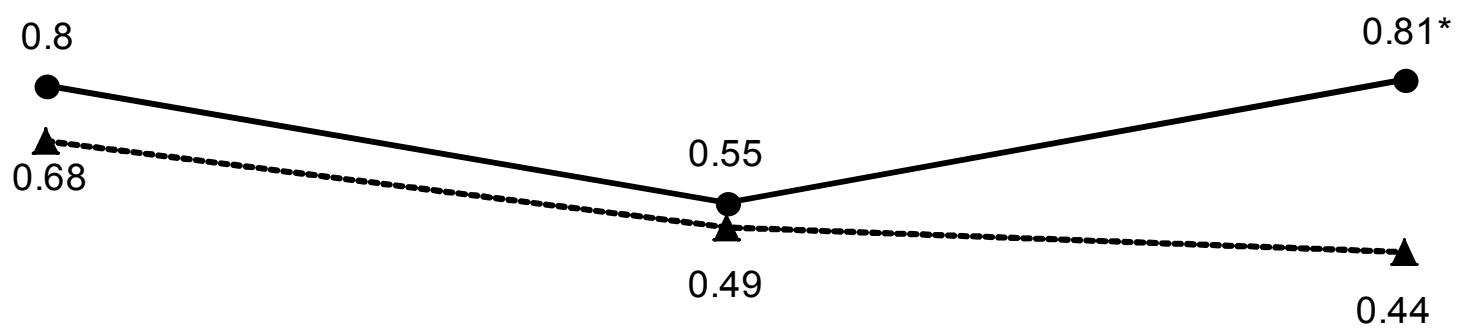

0

100

200

Doses of $\mathrm{N}\left(\mathrm{kg} \mathrm{ha}^{-1}\right)$

* $\mathrm{p}<0.05$ (Tukey test).

Figure 5 - Effect of the phenological stage in the concentration of catechin, epicatechin and caffeic acid in alcoholic extracts of tough lovegrass according to the nitrogen fertilization $(\mathrm{N})$. 
The flowered plants exhibited a higher response of the phenolic compounds to the $\mathrm{N}$ compared to those harvested at the vegetative stage, showing the effect of $\mathrm{N} x$ phenology interaction. Similarly to what happened to the allelopathic activity, with the intermediate dose of N, concentrations of phenolic acids different from the extreme doses were obtained (Figure 4). In general, when there is addition of $\mathrm{N}$ in the soil there is no decrease in secondary metabolites. Ibrahim et al. (2011) found a reduction of flavonoids, anthocyanins and ascorbic acid by increasing the $\mathrm{N}$ doses on "kacip fatimah" (Labisia pumila, Primulaceae) as well as a lower antioxidant power of its extracts, which may be related to a lower incidence of light in plants due to the increased vegetative growth caused by $\mathrm{N}$.

In coffee (Coffea arabica, Rubiaceae), a positive or negative quadratic response of the phenolic acids depending on the type of nitrogen fertilizer was observed (Malta et al., 2003). In wheat (Triticum aestivum, Poaceae), there is recording of the rising of phenolic acids by increasing the $\mathrm{N}$ (Ma et al., 2015). In crabgrass (Digitaria sanguinalis, Poaceae), the increase of $\mathrm{N}$ incremented the concentration of these acids (Chou and Lee, 1988). In sorghum, the synthesis of the dhurrin alkaloid is known to be influenced by the application of $\mathrm{N}$, demonstrating that the biosynthesis of some allelochemicals can be controlled by means of nitrogen fertilization (Inderjit and Duke, 2003).

Comparing the allelopathic activity and the concentration of allelochemicals, the most allelopathic extract (100VEG) was the one that showed the lowest concentrations of phenolic acids (Figure 4). However, there was no significant correlation between the concentrations of phenolic compounds and the attributes of the seed germination (data not shown). The catechin was the only compound in which a similar trend to allelopathic response was found (Figure 5). This procyanidin monomer has received attention for its inhibitory power over other plants, taking part in the successful invasion of the spotted knapweed (Centaurea maculosa, Asteraceae) in North America (Li et al., 2010) and in the allelopathic action of the black tachi (Tachigali myrmecophila, Leguminosae) (Lobo et al., 2008). Nevertheless, in other studies, the phytotoxic effects of the dwarf water clover (Marsilea minuta, Marsileaceae) on rice (Oriza sativa, Poaceae) and wheat were caused by the p-coumaric and m-coumaric acids (Tanveer et al., 2015). In any case, the allelochemicals activity depends on its concentration and may promote or inhibit the germination and the development of seedlings (Inderjit et al., 1999).

In this study one could speculate that the allelopathy of the 100VEG and 200REP extracts would be linked to the botanical composition of the vegetable material, for the greater or lesser proportion of leaves, or to the dry matter production. It seems to be a consensus that the leaf is the organ that contains the greatest diversity of allelochemicals, for it is the most metabolically active organ (Ribeiro et al., 2009). Furthermore, the higher dry matter and/or stems production could cause the dilution effect of chemical compounds. Nonetheless, considering the vegetative stage, there was no variation in the participation of leaves among $\mathrm{N}$ treatments (Figure 2). On the other hand, at the flowering stage, the intermediate dose of $\mathrm{N}$ had a lower participation of leaves in relation to other $\mathrm{N}$ treatments, which would not explain the effect of the proportion of leaves in allelopathy. Moreover, the highest production of DM occurred with the highest dose of $\mathrm{N}$ in plants harvested at the flowering stage, in which the extract was the second in allelopathic order, which discards the effect of dilution.

It is possible that in the plants harvested at the flowering stage and that were subjected to the highest dose of $\mathrm{N}$, a greater leaf renewal has occurred, with the participation of younger leaves in relation to the other $\mathrm{N}$ treatments. The plants harvested at this stage had 128 more days of growth compared to those harvested at the vegetative stage, which may have resulted in leaves of different ages and allelopathic profile. Since the nitrogen fertilization stimulates the leaves formation (Freitas et al., 2005) and the senescence involves the reduction of the metabolism (Paterson and Moss, 1979), the mixture of leaves with different chemical composition implies in variation in the allelopathic activity and in the composition of allelochemicals. This fact should be investigated and it should be quantified in vegetable material for such studies.

In studies of allelopathy, which combine biology and chemistry, the divergence of results may be due to several factors. Among these factors are the type of solvent and the analytical methods utilized. In this study, it is possible that the type of solvent used for the preparation of the extracts has determined the different response of the allelopathy and of the phenolic 
composition. Water was used to the evaluation of the allelopathic activity, and the acid-ethanol extraction was made in order to quantify the allelochemicals, with subsequent partitioning with ethyl acetate, resulting in a semi-purified fraction. Since the solubility of the phenolic compounds is partly controlled by the polarity of the solvent, there is an influence of the solvent in the efficiency of the extraction, thus reflecting in a greater or lesser recovery of the phenolic compounds (Liyana-Pathirana and Shahidi, 2005), with the possibility of loss of those compounds depending on the type of extraction (Naczk and Shahidi, 2004). The aqueous extraction simulates the conditions of leaching by rain water, however, the ethanol extraction is more effective to obtain secondary metabolites.

The use of ethanol as solvent enables the extraction of a greater number of substances that, when associated, would optimize the allelopathic activity. Moreover, the alkaline or acid hydrolysis is recommended to release phenolic acids that are linked to lignins and ester groups (Harborne, 1984; Dey and Harborne, 1989). Furthermore, the presence of organic and inorganic compounds, depending on their type and concentration, modify the inhibitory effects of the phenolic acids (Blum, 2011).

Another hypothesis to be tested is that the phenolic compounds that were evaluated in this study, although they are allelochemicals (Li et al., 2010), are not the main cause of allelopathy of the tough lovegrass. In the Eragrostis tenella (Poaceae), phenolic acids, glycosides, flavonoids, alkaloids, leucoanthocyanidins, saponins, fatty acids, steroids and emodins were verified (Ankanna et al., 2012), indicating the abundance of secondary metabolites of this type.

In the present study, there was an interactive effect of the phenological stage and the nitrogen fertilization on the allelopathic activity and on the phenolic content, which demonstrates that such factors should be considered in studies of this type. Regarding the tough lovegrass, the results can be used in further studies, enabling the management of the fertility and age of the plant harvest according to the phytochemical profile and/or the desired allelopathic potential. In natural pastures invaded by the tough lovegrass, nitrogen fertilization could increase the competitiveness of this weed, since this grass is responsive to this nutrient, which, in turn, increases the allelopathic activity, especially in plants in reproductive stage. Similarly, eventual mowing should be performed in the period prior to the flowering stage in order to reduce the presence of this grass in the pasture, since in the reproductive stage, the plants have an increase of several phenolic compounds, which are potentially allelopathic.

\section{ACKNOWLEDGEMENTS}

We would like to thank the "Coordenação de Aperfeiçamento de Pessoal de Nivel Superior (Capes)" by funding this study by maintaining scholarships for the first and second authors, to "Fundação de Amparo à Pesquisa do Estado do Rio Grande do Sul (Fapergs)" by the scholarships for the last author, and to "Conselho Nacional de Desenvolvimento Científico e Tecnológico (CNPq)" to support this work under project $\mathrm{n}^{\circ}$ 471427-6.

\section{REFERENCES}

Albuquerque M.B. et al. Allelopathy, an alternative tool to improve cropping systems. A review. Agron Sustain Dev. 2010;31:379-95.

Alfaya H., Sune L.N.P., Siqueira C.M.G. Efeito da amonização com ureia sobre os parâmetros da qualidade do feno do capimannoni 2. Rev Bras Zootec. 2002;31:842-51.

Ankanna S., Suhrulatha D., Savithramma N. Chemotaxonomical studies of some important monocotyledons. Bot Res Inter. 2012;4:90-6.

Blum U. Plant-plant allelopathic interactions: phenolic acids, cover crops and weed emergence. New York: Springer, 2011. 200 p.

Callaway R.M., Ridenour W.M. Novel weapons: invasive success and the evolution of increased ability. Front Ecol Environ. 2004;2:436-43. 
Chou C.H., Lee K.L. Effects of nitrogen fertilizer levels on the allelopathic potencial of pangola grasses and weeds. Bot Bull Acad Sin. 1988;29:39-47.

Çirak C., Radusiene J., Camass N. Pseudohypericin and hyperforin in two Turkish Hypericum species: Variation among plant parts and phonological stages. Biochem Syst Ecol. 2008;36:377-82.

Dey P.M., Harborne J.B. Methods in plant biochemistry. Plant phenolics. London: Academic Press, 1989. v.1. 552p.

Deschamps F.C., Ramos L.P. Método para a determinação de ácidos fenólicos na parede celular das forragens. Rev Bras Zootec. 2002;31:1634-9.

Favaretto A. et al. Growth of white clover seedlings treated with aqueous extracts of leaf and root of tough lovegrass. Rev Bras Zootec. 2011;40:1168-72.

Favaretto A. et al. Pattern of allelochemical distribution in leaves and roots of tough lovegrass (Eragrostis plana Nees). Austr $\mathbf{J}$ Crop Sci. 2015;8:1119-25.

Ferreira N.R., Medeiros R.B., Soares G.L. Potencial alelopático de capim-annoni-2 (Eragrostis plana Nees) na germinação de sementes de gramíneas estivais. Rev Bras Sementes. 2008;30:43-50.

Focht T, Medeiros R.B. Prevention of natural grassland invasion by Eragrostis plana Nees using ecological management practices. Rev Bras Zootec. 2012;41:1816-23.

Freitas K.R. et al. Avaliação do capim mombaça (Panicum maximum Jacq.) submetido a diferentes doses de nitrogênio. Acta Sci Agron. 2005;27:83-9.

Gobbo-Neto L., Lopes N.P. Plantas medicinais: fatores de influência no conteúdo de metabólitos secundários. Quím Nova. 2007;30:374-81.

Harborne J.B. Phytochemical methods: a guide to modern techniques of plant analyses. London: Chapman and Hall, 1984. 288p.

Hu F. et al. Effects of different water, soil fertility and light conditions on allelopathic traits of rice. Chin J Appl Ecol. $2003 ; 14: 2265-8$.

Ibrahim M.H. et al. Effects of nitrogen fertilization on synthesis of primary and secondary metabolites in three varieties of kacip fatimah (Labisia pumila Blume). Int J Molec Sci. 2011;12:5238-54.

Inderjit, Duke S.O. Ecophysiological aspects of allelopathy. Planta. 2003;217:529-39.

Jung H.G., Deetz D.A. Cell wall lignification and degradability. In: Jung G., Hatifield D.R. Forage cell wall structure and digestibility. Madison: American Society of Agronomy, 1992. p.315-46.

Inderjit, Asakawa C., Dakshini K.M.M. Allelopathic potential ofVerbesinaencelioides rootleachate in soil. Can J Bot. 1999;77:1419-24.

Li Z. et al. Phenolics and plant allelopathy. Molucules. 2010;15:8933-52.

Liyana-Pathirana C., Shahidi F. Optimization of extraction of phenolic compounds from wheat using response surface methodology. Food Chem. 2005;93:4747-56.

Lôbo L.T. et al. Potencial alelopático de catequinas de Tachigali myrmecophyla (sic) (Leguminosae). Quím Nova. 2008;31:493-7.

Luu K.T., Matches A.G., Peters E.J. Allelopathic effects of tall fescue on birdsfoot trefoil as influenced by N fertilization and seasonal changes. Agric J. 1982;74:805-8.

Ma D. et al. Effect of nitrogen fertilization and irrigation on phenolic content, phenolic acid content, phenolic acid composition, and antioxidant activity of winter wheat grains. J Sci Food Agr. 2015;95:1039-46.

Malta M.R. et al. Composição química, produção e qualidade do café fertilizado com diferentes fontes de nitrogênio. Cienc Agrotec. 2003;27:1246-52.

Marchi G. et al. Effect of age of a sorghum-sudangrass hybrid on its allelopathic action. Planta Daninha. 2008;26:707-16. 
Naczk M., Shahidi F. Extraction and analysis of phenolics in food. J Chromatogr. 2004;1054:95-111.

Oliveira S.C.C. et al. Estudo fitoquímico de folhas de Solanum lycocarpum A. St.-Hil (Solanaceae) e sua aplicação na alelopatia. Acta Bot Bras. 2012;26:607-18.

Omezzine F. et al. Variation in chemical composition and allelopathic potential of mixoploid Trigonella foenum-graecum L. with developmental stages. Food Chem. 2014;148:188-95.

Paterson T.G., Moss D.N. Senescence in field-grown wheat. Crop Sci. 1979;19:635-40.

Ribeiro J.P.N. et al. Efeitos alelopáticos de extratos aquosos de Crinum americanumL. Rev Bras Bot. 2009;32:183-8.

Rice E.L. Allelopathy. New York: Academic Press, 1984.

Silva F.A.S., Azevedo C.A.V. Versão do programa computacional Assistat para o sistema operacional Windows. Rev Bras Prod Agr. 2002;4:71-8.

Soares J.L.G., Vieira T.R. Inibição da germinabilidade e do crescimento radicular de alface (cv. "grandrapids") por extratos aquosos de cinco espécies de Gleicheniaceae. Flor Amb. 2000;7:180-97.

Souza Filho A.P.S., Rodrigues L.R.A., Rodrigues T.J.D. Efeitos do potencial alelopático de três leguminosas forrageiras sobre três invasoras de pastagens. Pesq Agropec Bras. 1997;32:165-70.

Su W.H., Yu S.W. Allelopathy and Its Potential Application. Plant Physiol Comm. 1992;28:81-7.

Wang Q. et al. Models analysis for allelopathic effects of chicory at equivalent coupling of nitrogen supply and $\mathrm{pH}$ level on F. arundinacea, T. repens and M. sativa. Plos One. 2012;7:1-10.

Tanveer A. et al. Assessing the potential of the water-soluble allelopaths of Marsilea minuta in rice and wheat. Planta Daninha. 2015;33:231-9.

Vieira S., Hoffmann R. Estatística experimental. São Paulo: Editora Atlas, 1989. 179p. 